\title{
The length of life and eugeria in classical Greece
}

\author{
Menelaos L. Batrinos \\ Emeritus Professor of Endocrinology
}

\begin{abstract}
Contrary to the commonly held belief that in antiquity and as late as 1700 A.D. normal lifespan was about 35 years, there are indications that the ancient Greeks lived longer. In a study of all men of renown, living in the 5th and 4th century in Greece, we identified 83 whose date of birth and death have been recorded with certainty. Their mean \pm SD and median lengths of life were found to be $71.3 \pm 13.4$ and 70 years, respectively. Although this cohort cannot be considered as representative of the general population, it is however indicative of a long length of life in classical Greece. Good living conditions and a mild climate at the time of intellectual and artistic excellence, the use of slaves for hard work, an animated social life in which the aged actively participated and, not least of all, the respect that aged people were accorded by the younger, all favored a longer length of life and eugeria (happy aging) or eulongevity in classical Greece.
\end{abstract}

Key words: Classical Greece, Eugeria, Length of life, Lifespan, Longevity

\section{INTRODUCTION}

A limited number of skeletal findings and demographic data have encouraged amongst scientists and laymen alike the general opinion that in ancient times and as late as 1700 A.D., the average length of life was about 35 years. This is routinely mentioned when reference is made to the progress in length of life observed over the last century as a means of emphasizing this human achievement. In ancient Greece, however, many men of fame are known to have lived longer lives characterized by eugeria [good(eu)aging]. Thus, although Angel, ${ }^{1}$ working on the basis of skeletal material, estimated the average age of death of adults to be 37.7-42.6 years in classical

Address for correspondence:

Menelaos L. Batrinos, 8 Evripidou Str., 14563 Politia, Greece, e-mail: bithrini@ath.forthnet.gr.

Received 10-10-07, Revised 20-11-07, Accepted 05-12-07
Greece, Montague, ${ }^{2}$ reported a median length of life of 72 years of Romans and Greeks living before the $1^{\text {st }}$ century B.C., with a decrease in the length of life after the $2^{\text {nd }}$ century B.C.

To compile data about longevity during the Golden Age of ancient Greece, namely the $5^{\text {th }}$ and $4^{\text {th }}$ century B.C., a study was carried out of the length of life of all renowned men living at that time, whose data of birth and death have been chronicled with certainty by grammarians and historians.

\section{METHODS AND RESULTS}

The Oxford Classical Dictionary, ${ }^{3}$ the Papyrus-Larousse Encyclopedia, ${ }^{4}$ the Great Lexicon of the Greek Language by Liddell and Scott $t^{5}$ and a recent thesaurus of all mythical and historical names, ${ }^{6}$ were consulted. All men living in Greece in the $5^{\text {th }}$ and $4^{\text {th }}$ century B.C. whose data of birth and death have been documented 
with certainty by grammarians and historians were included in this study. Those whose life was violently ended (by execution, murder, poisoning, disease or suicide) after the age of 50 were also included with the comment that their life is most likely to have been longer. A total of 83 persons were identified, whose mean $( \pm \mathrm{SD})$ and median length of life was $71.3 \pm 13.4$ and 70 years, respectively (Figure 1).

Among these, three centenarians-Aristarchos and Democritos, who lived over 100 years and Gorgias who died at the age of 108 years (483-275 B.C.) - are included.

\section{DISCUSSION}

A cohort of 83 eminent men of classical Greece comprises the only group of that time for which the dates of birth and death are precisely known. Their mean and median length of life has been found to be equal to that of the civilized populations of modern times. This is, needless to say, a select and restricted group, insufficient to be considered representative of

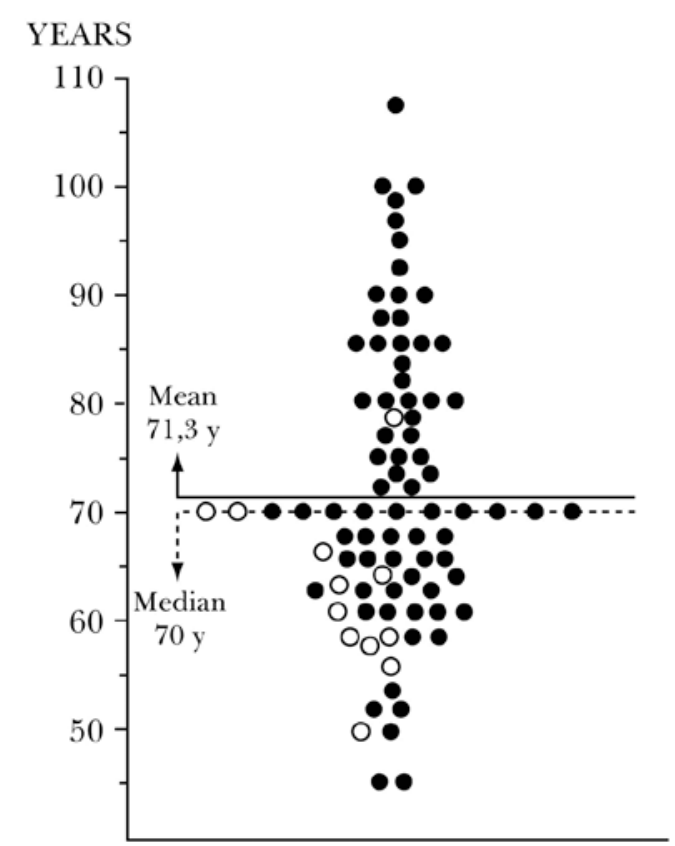

Figure 1. Individual values of the length of life of 83 men living in the 5th and 4th century B.C. in Greece (open circles indicate violent death). the general population. It is nevertheless indicative of a great length of life at the time when intellect and art flourished in Greece. It may be argued that the longevity of these people may have resulted from or been associated with a genetic or constitutional qualification that enabled them to perform their achievements and live long. It is true that almost all of them traveled much by sea and land at a time when the hardships of transportation necessitated physical strength and endurance; however, all these people have gone down in history on account of their intellectual excellence and achievements that had already been manifested and realized by the age of 30 or 40 years. Their fame had been acquired early in their life and living for a longer period of time enabled them to be more prolific in their creative activities.

Living conditions in classical Greece were favorable for longevity and eugeria (eulongevity); a mild climate, a good level of sanitary and hygienic conditions of housing, adequate nutrition and many slaves engaged for the hard work are highly likely to have conduced to long lifespans. However, possibly of the greatest import was an intense intellectual and an animated social life in which the aged actively participated, since it was common amongst the ancient Greeks to reflect on their own aging and consequently to show great respect for the aged. All these factors created an advantageous environment for eugeria and a longer length of life in classical Greece and offer an example for living not only long but also creatively. Thus, ancient Greece provided not only new scientific and very advanced ideas for their time but also a good paradigm of eugeria or eulongevity.

\section{REFERENCES}

1. Angel JL, 1946 The length of life in ancient Greece. Am J Gerontology 18: 18-24.

2. Montagu JD, 1994 Length of life in the ancient world: a controlled study. J Royal Soc Med 87: 25-26.

3. Oxford Classical Dictionary 1970 Oxford Clarendon.

4. Papyros Grand Larousse Encyclopédique (in Greek) 1963 Papyros (ed), Athens.

5. Liddell HG,Scott R, Great Lexicon of Greek Language. Sideris J (ed), Athens.

6. Megapanou A 2006 Mythical and historical persons (in Greek), Museum Benaki (ed), Athens. 